\title{
Production Response of Mung Bean (Vigna radiata L.) on the Application of Phosphorus Fertilizer and Oil Palm Bunch Ash
}

\author{
Faizan Muhammad Nasution, Yaya Hasanah*, and Mariati
}

Faculty of Agriculture, Universitas Sumatera Utara, Indonesia

\begin{abstract}
Mung bean need phosphate in seed formation and accelerate pod maturity. In acidic soil the $\mathrm{P}$ element is difficult to be available because it is bound by metal metals in the soil, it is given a palm bunch ash containing a lot of organic nutrients to release $\mathrm{P}$ from the metal and also increase soil $\mathrm{pH}$. The study aims to determine the effect of $\mathrm{P}$ fertilization and palm bunch ash on the growth and production of mung bean. The study was conducted on community land in Medan Selayang from October to December 2019. The study used a factorial randomized block design, with 2 factors. The first factor is $P$ fertilizer $(0 ; 37.5 ; 112.5$ $\mathrm{kg} \mathrm{SP}-36 / \mathrm{ha})$. The second factor is oil palm bunch ash consisting of $0 ; 2 ; 4 \mathrm{t} / \mathrm{ha}$. The variables observed were a number of pods, weight of 100 seeds, weight of seed per plots, weight of seed per plant. The results showed that the application of $\mathrm{P}$ the applications of $\mathrm{P}$ fertilizer $112.5 \mathrm{~kg} \mathrm{SP}-36 /$ ha tended to produce the highest pod number and seed weight per plot. The applications of oil palm bunch ash $2 \mathrm{t} /$ ha significantly increased seed weight per plant, seed weight per plot and pod number.
\end{abstract}

Keywords: mung bean, P fertilizer, oil palm bunch ash

Received 24 March 2020 | Revised 08 April 2020 | Accepted 15 May 2020

\section{Introduction}

Mung beans are one of legumes as source of vitamins (A, B1 and C), minerals, contains balanced nutrient, including protein, dietary fibers and significant amounts of bioactive compounds. The use of mung beans is very diverse, from simple processed to industrial processed products, food stuff, vegetable, livestock feed and medicine in India, China, Thailand and the Philippines. Besides being used as food, mung beans also have benefits as a cover crop and green manure [1] [2] [3] [4] [5] [6].

Mung beans have many health benefits such as hypoglycemic and hypolipidemis effects [7] [8], antihypertensive [9], anticancer [10], hepatoprotective [11] and immunomodulatory properties [12] and anti imflamatory [13]. Grains of mungbean is composed of $49.4 \%$ carbohydrates, $25 \%$

\footnotetext{
*Corresponding author at: Faculty of Agriculture, Universitas Sumatera Utara, Jl. Prof A. Sofyan No. 3, Kampus USU, Medan, Indonesia

E-mail address: yaya@usu.ac.id
}

Copyright (C) Indonesian Journal of Agricultural Research 2020 Published by Talenta Publisher p-ISSN: 2622-7681 | e-ISSN: 2615-5842 | DOI 10.32734/injar.v3i1.3839

Homepage Journal: https://talenta.usu.ac.id/InJAR 
proteins and 2-4\% fats, in addition to that they also contain 365 and $134 \mathrm{mg}$ of phosphorous and calcium per hundred grams of grains respectively [14].

Mung beans in Indonesia rank as the third most important legume food crop, after soybeans and peanuts. With this potential green beans can fill protein deficiencies in general, improve nutrition and simultaneously increased farmer income. Mung bean production in Indonesia in 2017 is 241,334 tons, and in 2018 the production of mung bean has decreased to 234,718 tons. Production from 2017 to 2018 decreased by $2.74 \%$ [15].

Mung beans have more value than other food crops, namely: (1) through early maturing (55-65 days), (2) more drought tolerant because it has deep roots (tap roots), (3) can be planted in less fertile land and can fertilize the soil, (4) easy cultivation method, and relatively few pests. Because there is more value than mung beans it can be seen as an alternative to be developed in dry land, specifically those that have a low harvest index [16] [17] [18]. Mung bean has high adaptation in environmental stress such as drought phase or poor fertility of soil status, and excellent soil fertility via nitrogen fixation. Therefore, mung beans are the first choice of farmers to cultivate it in different cropping patterns [19] [20] [22] [23].

Phosphorus $(\mathrm{P})$ is among the most needed elements for the legumes production in most tropical soils, which tends to be $\mathrm{P}$ deficient [24]. Some studies report that $\mathrm{P}$ deficiencies primarily result from other inherent low level of soil $\mathrm{P}$ or depletion through cultivation. Phosphorus has a vital role in plant nutrition by enhancing nitrogen absorption, influencing pods and seeds formation in legumes and contributing to plant energy processes [25] [26].

The application of $\mathrm{P}$ fertilizer together with ameliorant can reduce the available $\mathrm{Al}$ in the soil and soil acidity which causes the availability of $\mathrm{P}$ nutrients, $\mathrm{P}$ uptake of plants is higher so that the efficiency of $P$ fertilizer increases [27]. Availability of $P$ plays a role in the division of the cell nucleus to form new cells and enlarge the cells so that plant growth and development increases. The application of phosphate fertilizer can increase the photosynthesis process which in turn will also affect the increase in dry weight of plants [28].

The application of $\mathrm{P}$ fertilizer had significant effects on yield, pods per plant, and 100-seed weight. P deficiency suppresses growth and lowers yield, whereas, excessive amount of P delays maturation and seed set [29]. Previous researcher has reported that the application of P fertilizer has significant affects the age of harvest, number of pods per plant, number of pods per plot, weight of 100 mung bean seeds and pod weight per plot, but has no significant effect on plant height parameters and number of branches, age of mung beans flowering and pod weight per plant [30]. The application of oil palm long ash 2 tons/ha to mung beans has an influence on plant height, flowering age, harvest age, number of pods per plant, percentage of pods per plant, dry seed weight per plant and weight of 100 seeds [31]. 
Based on the background, the objective of the research was to evaluate the effect of $\mathrm{P}$ fertilization and palm bunch ash on the growth and production of mung bean.

\section{Materials and Methods}

This research was conducted in the field of Selayang sub-district community land, starting in October - December 2019. This study used a factorial randomized block design using two treatment factors, as follows: SP-36 fertilizer with 4 levels, P0: $0 \mathrm{~kg}$ SP- 36/ha, P1: $37.5 \mathrm{~kg}$ SP36/ha, P2: 75 kg SP-36/ha, P3: 112.5 kg SP-36/ha. Palm bunch ash with 4 levels namely, K0: 0 tons of oil palm bunch ash/ha, K1:2 tons of palm bunch ash/ha, K2: 4 tons of palm bunch ash/ha.

The research procedure started from land preparation, plot preparation ( $1 \mathrm{~m} \times 1.4 \mathrm{~m})$, application of palm bunch ash, planting, watering, weeding, application of $\mathrm{P}$ fertilizer, pest and disease control and harvesting. Variable observed were total of pods, weight of seed per plant, weight of 100 seeds. Data was analyzed using an analysis of variance and followed by a Duncan's Multiple Range Test with a level of $\alpha=5 \%$ for the treatment that has a significant effect.

\section{Results and Discussion}

\subsection{Number of Pods}

Table 1 showed that in the treatment of $4 \mathrm{t} / \mathrm{ha}$ of oil palm bunch ash produced the highest number of pods, namely 8.49 pods which were significant different from the application of $0 \mathrm{t} / \mathrm{ha}$ of palm bunch ash (control), but not significant different from the application of $2 \mathrm{t} / \mathrm{ha}$ of palm bunch ash. The treatment of $112.5 \mathrm{~kg} /$ ha of $\mathrm{P}$ fertilizer tends to have the highest number of pods ( 7.78 pods). Interactions between $\mathrm{P} 3 \mathrm{~K} 2$ tend to have more pods than other interactions.

Table 1. Effect of $P$ fertilizer and Palm Bunch Ash Applications on Pod Number of Mung Beans

\begin{tabular}{|c|c|c|c|c|c|}
\hline \multirow{2}{*}{$\begin{array}{l}\text { Oil palm bunch ash } \\
\text { (t/ha) }\end{array}$} & \multicolumn{5}{|c|}{ P fertilizer (kg SP-36/ha) } \\
\hline & $\begin{array}{l}\text { P0 } \\
\text { (0) }\end{array}$ & $\begin{array}{c}\text { P1 } \\
(37.5)\end{array}$ & $\begin{array}{c}\text { P2 } \\
\text { (75) }\end{array}$ & $\begin{array}{c}\text { P3 } \\
(112.5)\end{array}$ & Mean \\
\hline \multicolumn{6}{|c|}{ 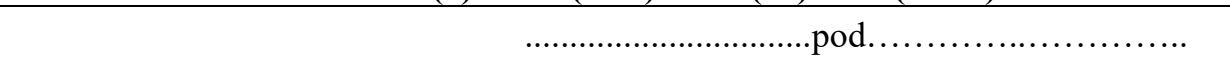 } \\
\hline K0 (0) & 6.40 & 5.20 & 5.27 & 5.40 & $5.57 \mathrm{~b}$ \\
\hline K1 (2) & 6.07 & 6.53 & 5.93 & 8.15 & $6.67 \mathrm{ab}$ \\
\hline $\mathrm{K} 2(4)$ & 9.00 & 7.17 & 8.00 & 9.80 & $8.49 \mathrm{a}$ \\
\hline Mean & 7.16 & 6.30 & 6,40 & 7.78 & \\
\hline
\end{tabular}

Note: The numbers followed by different letters column indicated significantly different based on Duncan's Multiple Range Test at the level of $\alpha=5 \%$

The results showed that an increase in $\mathrm{P}$ application tended to increase the number of pods. This is related to the role of $\mathrm{P}$ in the formation of pods as a sink from the resulting photosynthate translocation. Previous researcher stated that plant photosynthesis contributed to much of plant biomass accumulation and is highly sensitive to levels of $\mathrm{P}$ fertilization [32] [33]. $\mathrm{P}$ is an essential 
part of the cellular membrane, nucleic acid and is directly involved in the carbohydrate metabolism cellular and pods formation of legumes [34] [35].

\subsection{The Weight of Seeds per Plant}

Table 2 showed that in the treatment of $4 \mathrm{t} / \mathrm{ha}$ of oil palm bunch ash produced the highest seed weight per plant $(6.33 \mathrm{~g})$ which had a significant different effect with the treatment of 0 and 2 t/ha of oil palm bunch ash. The treatment of $112.5 \mathrm{~kg} \mathrm{SP}-36 / \mathrm{ha}$ has the highest number of pods $(5.17 \mathrm{~g})$.

Table 2. Effect of P fertilizer and Palm Bunch Ash Applications on Seed Weight of Mung Beans

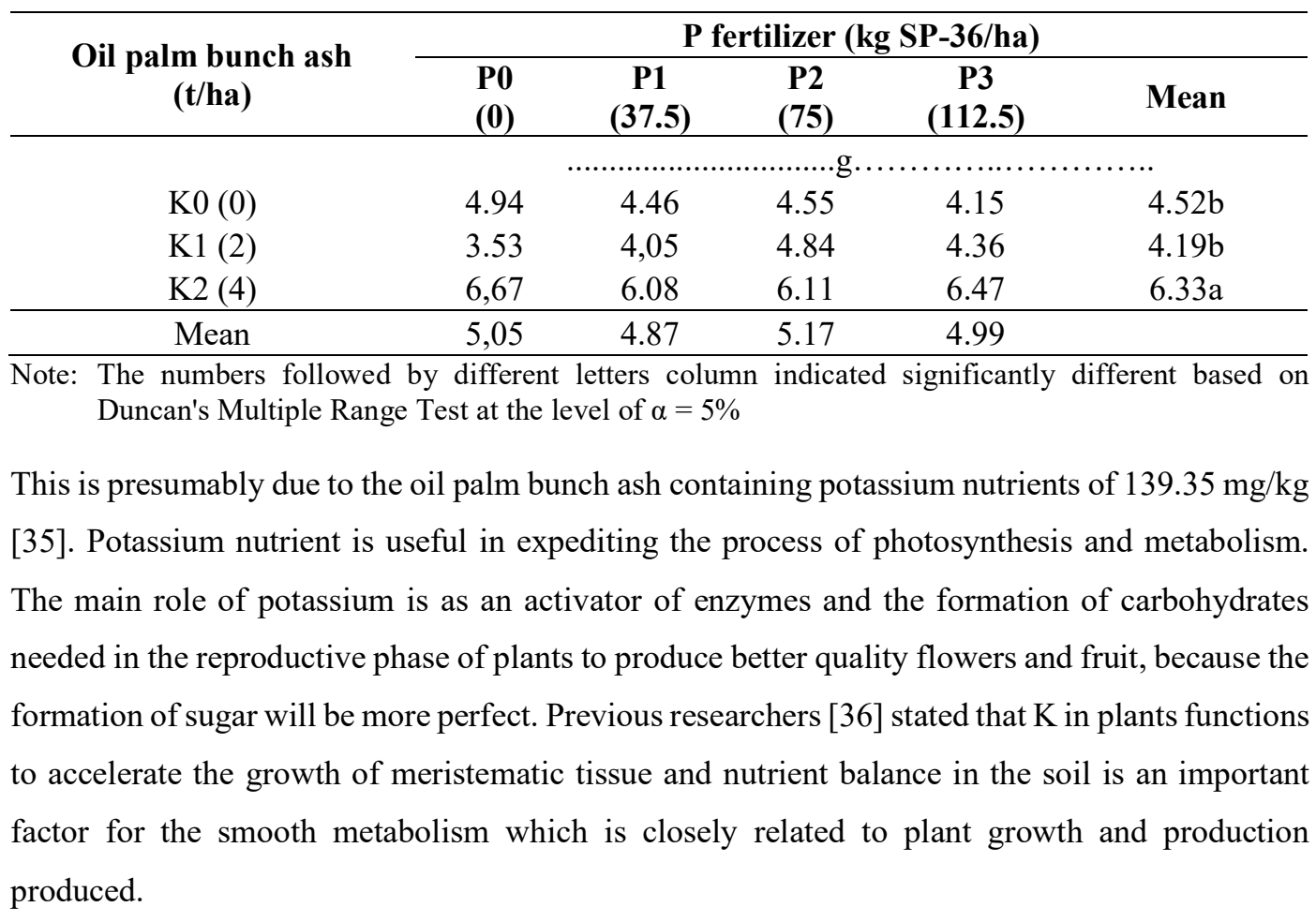

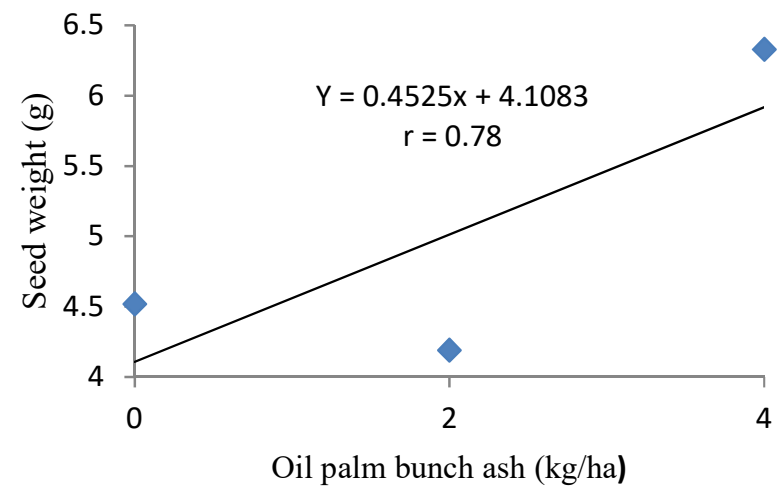

Figure 1. Relationship between Weight of seed/Plant and Dose of Palm Bunch Ash 
The relationship of seed weight per plant with the treatment of palm bunch ash can be seen in the Fig. 1, that showed a positive linear relationship between seed weight per plant and palm oil ash yield, with the equation $Y=0.4525 x+4.1083(r=0.78)$, that the number of pods increases with increasing palm bunch ash.

\subsection{Weight of Seeds Per Plot}

The results showed that the treatment of $\mathrm{P}$ fertilizer, the treatment of palm bunch ash, the interaction between the treatment of $P$ fertilizer and palm bunch ash did not significant affect the weight of seeds per plot (Table 3). The $\mathrm{P}_{3} \mathrm{~K}_{2}$ treatment produced the highest weight seed/plot (104.24 g/plot). The results is assumed that the available and given $P$ nutrients are bound by the metal elements $\mathrm{Al}$ and $\mathrm{Fe}$ in the soil. This is in accordance with Mitran et al. [38]. The most reported nutrient problems in acid soil are the low availability of $\mathrm{P}$ nutrients and high $\mathrm{P}$ fixation by $\mathrm{Al}$ and $\mathrm{Fe}$, the higher the $\mathrm{Al}$ or $\mathrm{Fe}$ content in the soil, the lower the $\mathrm{P}$ content available

Table 3. Effect of P Fertilizer and Palm Bunch Ash Applications on Weight of Seeds per Plot of Mung Beans

\begin{tabular}{|c|c|c|c|c|c|}
\hline \multirow{2}{*}{$\underset{(t / h a)}{\text { Oil palm bunch ash }}$} & \multicolumn{5}{|c|}{ P fertilizer (kg SP-36/ha) } \\
\hline & $\begin{array}{l}\text { P0 } \\
\text { (0) }\end{array}$ & $\begin{array}{c}\text { P1 } \\
(37.5)\end{array}$ & $\begin{array}{c}\text { P2 } \\
(75)\end{array}$ & $\begin{array}{c}\text { P3 } \\
(112.5)\end{array}$ & Mean \\
\hline & & ............. & ......... $\mathrm{g}$ & 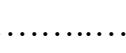 & ... \\
\hline $\mathrm{K} 0(0)$ & 71.59 & 61.59 & 62.40 & 74.82 & 67.60 \\
\hline K1 (2) & 69.59 & 64.61 & 74.25 & 70.90 & 69.83 \\
\hline K2 (4) & 91.40 & 60.40 & 80.47 & 104.24 & 84.13 \\
\hline Mean & 77.52 & 62.20 & 72.37 & 83.32 & \\
\hline
\end{tabular}

\subsection{The Weight of 100 Seeds}

The results showed that the treatment of $\mathrm{P}$ fertilizer, the application palm bunch ash, the interaction between the application of $\mathrm{P}$ fertilizer and palm bunch ash did not significant affect the weight of 100 seeds (Table 3). The treatment of P0K2 produced the higher than weight of 100 -seed of mung beans $(7.81 \mathrm{~g})$. This is allegedly due to the high $\mathrm{P}$ content in the field and the low $\mathrm{pH}$ of the soil which causes the $\mathrm{P}$ element to be bound and difficult to be absorbed by plants so that it does not have a real effect. This is in accordance with Mitran et al [38] which stated that usually in acid soils, the dominant micro nutrients are higher than the macro nutrients. If acidic soil $\mathrm{P}$ is available, it will be bound and cannot be broken down freely, making it difficult for the plant to absorb. 
Table 4. Effect of $P$ fertilizer and Palm Bunch Ash Applications on the Weight of 100-Seed of Mung Beans

\begin{tabular}{|c|c|c|c|c|c|}
\hline \multirow{2}{*}{$\begin{array}{l}\text { Oil palm bunch ash } \\
\text { (t/ha) }\end{array}$} & \multicolumn{5}{|c|}{ P fertilizer (kg SP-36/ha) } \\
\hline & $\begin{array}{l}\text { P0 } \\
(\mathbf{0})\end{array}$ & $\begin{array}{c}\text { P1 } \\
(37.5)\end{array}$ & $\begin{array}{c}\text { P2 } \\
(75)\end{array}$ & $\begin{array}{c}\text { P3 } \\
(112.5) \\
\end{array}$ & Mean \\
\hline & & ................ & .........g & ........ & .. \\
\hline K0 (0) & 7,05 & 6.74 & 7.19 & 7,76 & 7.19 \\
\hline K1 (2) & 6.91 & 6.91 & 6.88 & 6,67 & 6,84 \\
\hline K2 (4) & 7.81 & 6.76 & 7.14 & 6,92 & 7.16 \\
\hline Mean & 7.26 & 6,80 & 7.07 & 7,12 & \\
\hline
\end{tabular}

\section{Conclusion and Recommendation}

The applications of $\mathrm{P}$ fertilizer $112.5 \mathrm{~kg}$ SP-36/ha tended to produce the highest pod number and seed weight per plot. The applications of $2 \mathrm{t} /$ ha of oil palm bunch ash significantly increased seed weight per plant, seed weight per plot and pod number.

\section{REFERENCES}

[1] F. H. Brishti, et al., "Evaluation of the functional properties of mung bean protein isolate for development of textured vegetable protein," International Food Research Journal, vol. 24, no. 4, pp. 1595-1605, 2017.

[2] R-Y Gan, et al., "Bioactive compounds and bioactivities of germinated edible seeds and sprouts: An updated review," Trends Food Sci. Technol. vol. 59, pp. 1-14, 2017. doi: 10.1016/j.tifs.2016.11.010.

[3] P. K. Dahiya, et al., "Mung bean: technological and nutritional potential," Crit. Rev. Food Sci. Nutr., vol. 55, pp. 670-688, 2015. doi: 10.1080/10408398.2012.671202.

[4] D. Hou, et al., "Mung bean (Vigna radiate L.): bioactive polyphenols, polysaccharides, peptides, and health benefits," Nutrients, vol. 11, no. 6, p. 1238, 2019. https://doi.org/10.3390/nu11061238

[5] P. K. Dahiya, M. J. R. Nout, and M. van Boekel, "Nutritional characteristics of mung bean foods," British Food Journal, vol. 116, no. 6, pp. 1031-1046, 2014.

[6] C. Hall, C. Hillen, and J. G. Robinson, "Composition, nutritional value, and health benefits of pulses," Cereal Chem, vol. 94, pp. 11-31, 2017.

[7] B. Singh, J. P. Singh, K. Shevkani, N. Singh, and A. Kaur, "Bioactive constituents in pulses and their health benefits," J. Food Sci. Technol, vol. 54, pp. 858-870, 2017.

[8] Y. H. Jang, M. J. Kang, E. O. Choe, M. Shin, and J. I. Kim, "Mung bean coat ameliorates hyperglycemia and the antioxidant status in type 2 diabetic $\mathrm{db} / \mathrm{db}$ mice," Food Science and Biotechnology,vol. 23, pp. 247-252, 2014. doi: 10.1007/s10068-014-0034-3.

[9] J. Xie, M. Du, M. Shen, T. Wu, and L, Lin, "Physico-chemical properties, antioxidant activities and angiotensin-I converting enzyme inhibitory of protein hydrolysates from Mung bean (Vigna radiate)," Food Chemistry, vol. 270, pp. 243-250, 2019. 10.1016/j.foodchem.2018.07.103

[10] S. K. Yeap, et al., "In Vivo immunomodulation and lipid peroxidation activities contributed to chemoprevention effects of fermented mung bean against breast cancer," Evidence based complementary and alternative medicine, pp. 4-22, 2013. 
[11] L. A. R. Lopes, et al., "Cholesterol-lowering and liver-protective effects of cooked and germinated mung beans (Vigna radiate L.)," Nutrient, vol. 10, no. 7, pp. 821, 2018.

[12] K. Ketha and M. Gudipati, "Immunomodulatory activity of non starch poly-saccharides isolated from green gram (Vigna radiata)," Food Research International, vol. 113, pp. 269276, 2018. doi: 10.1016/j.foodres.2018.07.010.

[13] N. M. Ali, et al., "Anti-inflammatory and antinociceptive activities of untreated, germinated, and fermented mung bean aqueous extract," Evid.-Based Complement. Altern. Med., 2014.

[14] F. Anwar, S. Latif, B. Sultana, and M. Ashraf, "Chemical composition and antioxidant activity of seeds of different cultivars of mung bean" J Food Sci, vol. 72, no. 7, pp. S503S510, 2007.

[15] Kementerian Pertanian, "Data lima tahun terakhir sub sector tanaman pangan" https://www.pertanian.go.id/home/?show=page\&act=view\&id=61, 2018.

[16] P. Kumar, M. Pal, R. Joshi, and R. K. Sairam, "Yield, growth and physiological responses of mung bean [Vigna radiata (L.) Wilczek] genotypes to waterlogging at vegetative stage," Physiol Mol Biol Plants, vol 19, no. 2, pp. 209-220, 2013. doi: https://doi.org/10.1007/s12298-012-0153-3

[17] P. Singh and B. B. Singh, "Breeding for tolerance to abiotic stresses in mungbean," Journal of Food Legumes, vol. 24, no. 2, pp. 83-90, 2011.

[18] C. G. Abdel and I. M. T. Al-Rawi, "Response of mungbean (Vigna radiata L., Wilczek) to gibberellic acid (GA3) rates and varying irrigation frequencies," International Journal of Biosciences, vol. 1, no. 3, pp. 85-92, 2011.

[19] R. M. Nair, et al., "Genetic improvement of mungbean," SABRAO J Breed Genet, vol. 44, pp. 177-190, 2012.

[20] E. Kaya, "Perilaku fosfat dalam tanah, serapan fosfat, dan hasil jagung (Zea mays L.) akibat pemberian pupuk fosfat dengan amelioran pada typic dystrudepts, Disertasi, Universitas Padjadjaran, Bandung, 2003.

[21] F. Wahid, et al., "Arbuscular mycorrhizal fungi improve the growth and phosphorus uptake of mung bean plants fertilized with composted rock phosphate fed dung in alkaline soil environment," Journal of Plant Nutrition, vol. 42, no. 15, pp. 1760-1769, 2019. doi: 10.1080/01904167.2019.1643371

[22] D. S. Dharwe, H. C. Dixit, C. K. Dotaniya, A. Khandagle, S. Mohbe and R. K. Doutaniya, "Effect of phosphorus and sulphur on the yield \& nutrient content of green gram," International Journal of Chemical Studies, vol. 7, no. 2, pp. 01-05, 2019.

[23] Y. Habibzadeh and M. Yagoob, "The effects of water deficit stress on protein yield of mung bean genotypes," Peak Journal of Agricultural Science, vol. 2, no. 3, pp. 30-35, 2014.

[24] H. Malhotra, Vandana, S. Sharma, and R. Pandey, "Phosphorus nutrition: plant growth in response to deficiency and excess," in Plant Nutrients and Abiotic Stress Tolerance, 2019.

[25] P. S. Bindraban, C. O. Dimkpa, and R. Pandey, "Exploring phosphorus fertilizers and fertilization strategies for improved human and environmental health," Biol Fertil Soils, vol. 56, pp. 299-317, 2020. doi: https://doi.org/10.1007/s00374-019-01430-2

[26] Z. Yin, et al., "Nitrogen, phosphorus, and potassium fertilization to achieve expected yield and improve yield components of mung bean," PLOS ONE, vol. 13, no. 10, 2018. doi: https://doi.org/10.1371/journal.pone.0206285

[27] C. Jian et al., "Effects of fertilizer on physiological and biochemical characteristics in leaves of different plant types of mung bean," Crops, vol. 5, pp. 76-81, 2012.

[28] R. Thuynsma, A. Kleinert, J. Kossmann, A. J. Valentine, and P. N. Hills, "The effects of limiting phosphate on photosynthesis and growth of Lotus japonicas," South African Journal of Botany, vol. 104, pp. 244-248, 2016. 
[29] A. Hussen, W. Worku, and M. Zewdie, "Effects of deficit irrigation and phosphorus levels on growth, yield, yield components and water use efficiency of mung bean (Vigna radiata (1.) Wilczek) at alage, Central Rift Valley of Ethiopia," Agri Res \& Tech: Open Access J., vol. 21, no. 3, 2019. doi: 10.19080/ARTOAJ.2019.21.556167

[30] N. S. Kustiawan, S. Zahrah, and Maizar, "Pemberian pupuk TSP dan abu janjang kelapa sawit pada tanaman kacang hijau," Jurnal RAT, vol. 3, no. 1, 2014.

[31] Y. Mumpung and A .B. Samiputra, "Pengaruh waktu pemberian dan dosis amelioran abu janjang kelapa sawit terhadap pertumbuhan dan hasil kedelai (Glycine max (L). Merrill) di tanah gambut Palangka Raya, Agrisilvika, vol. 1, no. 1, pp. 14-21, 2017.

[32] S. K. Singh and V. R. Reddy, "Response of carbon assimilation and chlorophyll fluorescence to soybean leaf phosphorus across $\mathrm{CO} 2$ : alternative electron sink, nutrient efficiency and critical concentration," Journal of Photochemistry and Photobiology B: Biology, vol. 151, pp. 276-284, 2015.

[33] G. Xu, et al., "Soybean grown under elevated $\mathrm{CO} 2$ benefits more under low temperature than high temperature stress: varying response of photosynthetic limitations, leaf metabolites, growth, and seed yield," J. Plant Physiol, vol. 205, pp. 20-32, 2016.

[34] C. R. Warren, "How does P affect photosynthesis and metabolite profiles of Eucalyptus globulus?," Tree Physiol, vol. 31, pp. 727-739, 2011.

[35] I. Udoetok, "Characterization of ash made from oil palm empty fruit bunches (oefb)," International Journal of Environmental Sciences, vol. 3, no. 1, 518-524.

[36] Suryantini," Effect of phosphorus, organic and biological fertilizer on yield of mungbean (Vigna radiata) under two cropping patterns," Nusantara Bioscience, vol. 8, no. 2, pp. 273277, 2016.

[37] F. Hussain, et al., "Growth and yield response of mungbean to different levels of potassium," International Journal of Agricultural and Environmental Research, vol. 2, no. 1, pp. 67-74, 2016.

[38] T. Mitran, R. S. Meena, R. Lal, J. Layek, S. Kumar, and R. Datta, "Role of soil phosphorus on legume production," in Legumes for Soil Health and Sustainable Management, R. S. Meena, A. Das, G. S. Yadav, and R. Lal, Ed. Springer, 2018. 